\title{
A Confrontation on Gwendolyn Willow Wilson's Alif The Unseen: A Study of Postmodernism
}

\author{
Ninik Afriani \\ Pusat Kegiatan Belajar Masyarakat Citra Ilmu Semarang \\ ninikafriani178@gmail.com \\ Endang Suciati \\ Universitas Pesantren Tinggi Darul Ulum Jombang \\ suciati24@gmail.com
}

\begin{abstract}
This project aims to give an analysis of the signs of confrontation in terms of postmodernism strategies by Brian McHale experienced by the main character in Gwendolyn Willow Wilson's Alif The Unseen. Besides, the researcher analyzed the novel used the theory by Jean Francois Lyotard and Fredrich Jameson to describe the main character's reaction toward ontological confrontation in postmodern society used in the novel. This article is qualitative research which used the Postmodernism studies to understand one of the strategies to show the ontological confrontations in the novel. This article elaborated some ontological confrontations in postmodernism including confrontation between the fiction and the historical realemes, the fusion between two worlds, and also polyglot. Meanwhile, this article also classified the main character's reaction toward the ontological confrontation in 5 reactions: refusal reaction, skeptical reaction, curiousity reaction, surprise reaction, and acceptance reaction. It can be concluded that Alif as the part of Postmodern society must recognized the jinn creatures around him as the hacker who has the high ability and dependency of the technology.
\end{abstract}

Keywords: Confrontation, Alif The Unseen, Postmodernism

\begin{abstract}
Abstrak
Penelitian ini bertujuan untuk memberikan analisis terhadap tanda-tanda konfrontasi dalam hal strategi postmodernisme oleh Brian McHale yang dialami oleh tokoh utama dalam Alif The Unseen karya Gwendolyn Willow Wilson. Selain itu, peneliti menganalisis novel menggunakan teori oleh Jean Francois Lyotard dan Fredrich Jameson untuk menggambarkan reaksi karakter utama terhadap konfrontasi ontologis dalam masyarakat postmodern yang digunakan dalam novel. Penelitian ini merupakan penelitian kualitatif yang menggunakan studi Postmodernisme untuk memahami salah satu strategi untuk menunjukkan konfrontasi ontologis dalam novel. Artikel ini menguraikan beberapa konfrontasi ontologis dalam postmodernisme termasuk konfrontasi antara fiksi dan kenyataan sejarah, fusi antara dua dunia, dan juga polyglot. Sementara itu, artikel ini juga mengklasifikasikan reaksi karakter utama terhadap konfrontasi ontologis dalam 5 reaksi: reaksi penolakan, reaksi skeptis, reaksi rasa ingin tahu, reaksi kejutan, dan reaksi penerimaan. Dapat disimpulkan bahwa Alif sebagai bagian dari masyarakat Postmodern harus mengakui makhluk jin di sekitarnya sebagai peretas yang memiliki kemampuan tinggi dan ketergantungan teknologi.
\end{abstract}

Kata kunci: Konfrontasi, Alif The Unseen, Postmodernisme 


\section{INTRODUCTION}

The ontological confrontation according to McHale (1987:61) is "the confrontation which occurs between our world and some other world or worlds somehow adjacent or parrallel to our town, accessible across some kind of boundary barrier". In McHale's view, he thought that the interaction between some different worlds could create the ontological confrontation. To manage the confrontation between two worlds, Darko Suvin who continued by Mark Rose, cited from McHale (1987:60) obtained two strategies; first is "to transport representatives of our world to a different world, and the second is it's inverse, which 'involves another world's intrusion into this one." These strategies can be combined each other to make the worlds in a fiction live adjacent or even become unity. However, there have no deep research in Alif The Unseen about the confrontation especially in postmodernism which dominantly analyzed in ontological boundaries.

Jean Francois Lyotard in his book The Postmodern Condition: A Report on Knowledge (1984) explained that the principal or the form of science and technology in pre-modern and modern are based on a unity in a grand-narrative. But in Postmodernism, there is a denial in this grand-narrative and building meta-narrative as the main point in literature. It criticized the structuralism approach which give a priority to the objective meaning of analyzing the whole text. Ihab Hassan (2001:3) said that Postmodernism refers to the cultural sphere, especially literature, philosophy, and the various arts, including architecture, while postmodernity refers to the geopolitical scheme, less order than disorder, which has emerged in the last decades. The idea of postmodernism now no longer exclusively used in arts, its is now covering the limitless aspects such as in literature, business, politics, humanities and etc. Since postmodernism has very broad scope, this research only focused on one of the strategies to show the dominant of postmodernism in literature, which is ontological confrontation. It has three signs to set out the ontological aspect in a literary works, they are confrontation between the fiction and historical realemes, the fusion between two worlds, and polyglot which are used in Gwendolyn Willow Wilson's Alif The Unseen. This research also analyzed the main character's reaction toward the ontological confrontation in five expressions, they are refusal reaction, surprise reaction, skeptical reaction, curiousity reaction, and acceptance reaction. Therefore, there are two questions that will be discussed here. They are what the confrontation in terms of postmodernism found in Wilson's Alif the Unseen and how the confrontation's reaction experienced by the main character of Alif the Unseen in terms of postmodernism. 


\section{RESEARCH METHOD}

The goal of this research is to describe the confrontation in terms of postmodernism found in Wilson's Alif The Unseen and to explain the confrontation's reaction experienced by the main character of Alif The Unseen in terms of postmodernism. The method chosen to analyze the problem is qualitative research since it is aimed at describing the confrontation in terms of postmodernism found and the confrontation's reaction experienced by the main character in terms of postmodernism.

\section{FINDINGS AND DISCUSSION}

\section{A. Signs of Confrontation in Postmodernism}

McHale stated that the dominant of modernist fiction is epistemological while the dominant of postmodernist fiction is ontological. He showed that there are 2 strategies to set out ontological aspect in a fiction, they were confrontation among the worlds in a fiction that shows the world's plurality, and the strategy to destabilize the world had built in a fiction which set out the formation of the universe in a fiction (McHale, 1992: 152). These 2 strategies are used in his book which analyzed a novel entitled The Name of The Rose to use postmodernism repertoire. This research focused on the first strategies to set out the ontological aspect in a fiction, which is the confrontation among the worlds in a fiction that shows the world's plurality.

Gwendolyn Willow Wilson's novel can be analyzed using the first strategies to set out the ontological aspect in a fiction, because it contains the world's plurality that emerges the different worlds build by some signs. They are:

\section{- Confrontation between The Fiction and Historical Realemes}

In the statement from McHale which said about the constraint of inserting realemes, one of them is free to use the "dark areas" in historical figures, where the official record cannot report what actually happen inside the figures. In the historical realemes, one of the historical figures behind the Arab Spring is Mohamed Bouazizi, a civil worker from Tunisia who unable to find work and selling fruit at a roadside stand. He chose to burn himself in response to strive for his protest to the government. This figure has not been uncovered by the history, so the author used it as a space to create a new figure as the influential character. In the fiction, Wilson introduces Alif as the main character, who initiates the confrontation between the fiction and historical realemes. 
As the main character in the fiction, Alif has a unique character that brings him into the wonderful journey of revealing a history in a story. His journey takes him him to investigate the origin of something which are competed by him and The Hand as the State Security. He has a copy of Alf Yeom, actually known as The Thousand and One Days book, the secret book of the jinn. While he realized that Alf Yeom has more than just story, he must struggle for life and death to prevent the book found and abused by the Hand from the evil intention during the Arab Spring.

One of the stories in Alf Yeom is the tale of Princess Farukhuaz, which told about a princess who was very beautiful and beloved by every man, but every man cannot grab the princess' heart. Alif felt a doubt about the secret strength inside the Alf Yeom which was told by Vikram The Vampire. He felt that the story in Alf Yeom is just like The Thousand One Nights.

"What a rare idiot it is,"scoffed Vikram. "The Thousand and One Days is not just a bunch of old tales, little pimple. That title is no accident-this is the inverse, the overturning of The Nights. In it is contained all the parralel knowledge of my people, preserved for the benefit of future generations. This is not the work of human beings. This book was narrated by the jinn." (Wilson, 2012:103)

According to this fiction, Vikram as the Vampire as the supporting character emphasized that The Thousand and One Days is not just a bunch of tales, but it contained all the parralel knowledge of people to preserve for the benefit of future generations which is written by jinn. In fact, the historical realemes told that The Thousand and One Nights is only a middle story folk tales that were originally the collection drawn from the Pahlavi Persian work Hezār Afsān (Persian: A Thousand Tales) and dominantly used the Indian elements (Marzolphpa, 2007). This could emerge the confrontation between the fiction and the historical realemes.

\section{- The Fusion between Two Worlds}

Alif as the main character in Alif The Unseen has a rational thinking that there is impossible to meet the jinn even interact each other. He felt that he insisted by the condition to be aware with the jinn's existence. Of course he didn't know what he had to do when he met Vikram The Vampire in a sudden. One of the dialogue which shows this confrontation can be found in the following quotation:

"V-Vikram?” Alif managed finally.

"George Bush. Santa Claus.” The man grinned, displaying a set of white teeth.

"Are you going to hurt us?" Dina spoke in a wispy voice Alif barely recognized.

"I might. I easily could. In fact, I may without even realizing." 
The man shifted, and Alif noticed with horror that his knees seemed to bend the wrong way. He looked back at his face and attempted to forget. (Wilson, 2012:91)

The quotation above shows that the confrontation can occur in the fusion between two worlds and it affects on the attitude in each character. Everything could be so different compared with the reality, such as the representative of the jinn's world, Vikram The Vampire. Vikram spoke with Alif, Dina, and the other characters directly. Sometimes, he tossed some intelligent jokes and also argumentative opinions which are really different with the jinn/genies usually do. As the Moslem jinn, he could talk with the human easily. It fused the ontological constraints between the worlds inside.

\section{- Polyglot}

The last strategy to show the ontological confrontation in Postmodernism is the polyglot phenomenon in a fiction. Polyglot in a literal meaning is 'more than one language', or multilanguage. It means that there are different languages used in a text, although it has been translated into a certain language. In Alif The Unseen, there are different languages used as a tool to form the different world.

The different languages used by the characters also can give the broader knowledge of each terms across countries. Every terms in a language gives a different meaning to another language, so it will enrich the knowledge of how people in certain country understand a language beyond their daily language. As what can be showed in the following quotation:

"What do you mean, word whose meanings evolved?" asked Alif." That doesn't make sense. The Qur'an is the Qur'an."

Vikram folded his legs-Alif did not watch this operation closely-and smiled at his audience.

"The convert will understand. How do they translate ذرة in your English interpretation?"

"Atom," said the convert. (Wilson, 2012:207)

The quotation above shows the interpretation of the term ذرة in Arabic translated as Atom in English. The original meaning of زرة actually refers to the smallest indivisible particle in the world, but the representation of this will change based on the growth of people's knowledge, first was a grain of sand, then a dust, a cell, a molecule, atom, and so on (Wilson, 2012:208). At that time, the American convert understand the term ذرة as an atom because atom was the tiniest object known in the world, tomorrow it might be hadron, quark, and so on (Wilson, 2012:207). The polyglot phenomenon is evidently shown in this 
context, when the different languages can form the different understandings, and it will grow based on people's knowledge.

\section{B. The Main Character's Reaction toward Confrontations}

Postmodernism criticized that there are no impossible to told something without the rationality of science and the dichotomy thinking, because the reality told objectively. Postmodernism brings the plurality, which become the reaction against the modernism emerged since 19th century. The postmodernists themselves generally does not like the standardization, definition and limitation which possessed by modernist, but otherwise their concept are emphasized on the differences, diversity, and anti-essential, which could create the pluralism (Lubis, 2016:15). The concept of plurality in culture, religion, families, races, tribes and languages are the component of reality, which more understood by the society.

This subchapter analyzes Alif's reaction as the main character in Alif The Unseen novel which deals with the ontological confrontation. Alif lives in the 21 's era which have a high civilization when his beliefs about the modernity is glorified, while he has realized yet about the shift of postmodern era, that have the point of reaction against anything modernly organized (Jameson in Kaplan, 1988: 18). Alif thinks that the condition of society in his era has the rapid growth of technology, human resources, economy and so many sectors. The rationality influences Alif's mindset significantly, when he should understand that actually he lived in the tendency of postmodern society which dominantly criticize on how the modernity affects on their life.

\section{- Refusal Reaction}

As the main character, Alif lived in a way that mostly human do as a hacker that has the rational thinking and suddenly he has to accept the fact that he lived and even had to interact with the jinn tribe. There is a shift of thinking in Alif itself, that he has to change his rational thinking into the belief of metaphysical truth, which belongs to postmodernism. One of the data can be showed in the following quotation:

"But..." Alif attempted to collect his thoughts."Alleys don't move. So how could the entrance be somewhere other than where it used to be?"

"It moves."

"But it's called the Immovable Alley!"

"The alley is stationary. That's the whole point. The world moves around it. So entrances and exits can pop up anywhere." Vikram smiled, evidently pleased with himself. (Wilson, 2012:154)

This quotation shows Alif's reaction toward the fusion between two worlds, when Alif and his friends would go to a place where they can find out exactly the Alf Yeom book comes. In a literal meaning, The Immovable Alley that Alif thought was impossible to move 
for the entrance to somewhere, but Vikram said it can. It made Alif contradicted with Vikram's statement, so he affirmed the negation by questioning why must being named as The Immovable Alley. This reaction belongs to the refusal reaction, which caused by the ontological confrontation between two worlds that fused each other.

\section{- Skeptical Reaction}

To live in a fantasy-like in his life, Alif has to accept many facts regarding to the consequences when his lover give him more than just a regular book, which is the Alf Yeom. His job as a hacker accidentally disturbed with the accusation, anxiety, and terrorism, due to The Hand's obsession to get the Alf Yeom from him. When he was in a way to find someone giving him a protection against the Hand, his metaphysical journey began. This causes several skeptical reactions made by Alif as the main character.

\section{- Curiosity Reaction}

Alif encontered that there are many confrontations faced by him regarding to his journey seeking for the justice during the Arab Spring. He met the extraordinary experiences to know the creatures beyond his knowledge, the places he never met, the uprisings around The City and he also fight against the authoritarian of The Hand as the State Security. These experiences occurs behind his serious research to create the platform inspired from the Alf Yeom, that still on his way to reveal the truth in Alf Yeom. He filled his thought with the curiosity, because there might be so many information Alif wants to obtain.

A curiosity reaction due to the confrontation between the fiction and the historical realemes can be shown on the culmination of Arab Spring when Alif saw mass of protesters on the street, marching dozens deep across the breadth of the boulevard, holding signs and placards in Arabic, English, and Malay (Wilson, 2012: 380). Alif wondered about what happens to them, what they wanted when they all gather to the street. Dina said that the people want to get a justice for revolution.

"How can we be sure it's really a revolution?" asked Alif, hoping despite himself that it was not; he could talk of freedom but would readily have settled for familiarity.

"Of course it's a revolution. Did you see the number of women in the streets, Last week it would have taken a forklift to get those same ladies out of their houses. The emir is doomed." (Wilson, 2012:384)

The quotation above shows Alif's question to Dina about what makes them sure that it was a revolution. Dina said that there were number of woman in the street, when the government announced that the emir was doomed. It was obviously can be concluded as a 
revolution, and there would be the involvement of The Hand that took benefit behind the chaos hapened in the City.

\section{- Surprise Reaction}

Alif experienced many events that implied on his surprise, when he had to recognize the strength beyond his rational thinking. The strength that owned by the creatures came around him for a reason. At the point, the main character of Alif The Unseen reacts with expression of startling that would be differ, depends on the situation he found. The surprise reaction could occur when there was unpredictable thing done by someone, or owned by something. One of the following quotation which expressed Alif's reaction is as follows:

"She can't quite see me as I am,"he said."It's an American quirk. Half in, half out. A very spiritual people, but in their hearts they feel there is something shameful about the unseen. You'd be right at home there, younger brother."

Alif was startled by the precision with which Vikram had guessed his thoughts. Perharps he had been staring too openly. (Wilson, 2012: 130)

From the quotation above, Vikram showed his ability to tell anyone's secret only by seeing them, and Alif found that there is the precision of Vikram's guess. When Vikram met The Convert, Vikram could say all things about The Convert who could not quite see Vikram. It made Alif surprised because Vikram could do that thing in a sudden. Alif also surprised when he was in a research with the Convert to investigate the composition of the Alf Yeom paper. The Convert is a book scientist who can find from where Alif's lover got the manuscript and where it originated (Wilson, 2012: 125).

\section{- Acceptance Reaction}

The last reaction of the main character toward the ontological confrontation is an acceptance. It is a reaction when finally Alif as the main character accept the condition around him, which was fulfilled with the metaphysical experience he could not imagine before. He found his courage, confidence, and bravery to behave with any creatures, including Vikram The Vampire, Azalel, Sakina, The Effrit and the other jinn tribe, also The Hand as his true human enemy. Some conditions of Alif represented his acceptance, one of them is when he successfully escaped from the State Security Prison with Sheikh Bilal and New Quarter.

Wandering toward the mirage, Alif considered their situation. He was not frightened or anxious; his fear of death had dulled during the weeks he had spent awaiting it. He thought about what Vikram had said, about the Empty Quarter containing not just desert but a world turned sideways - the abode of the jinn... (Wilson, 2012: 300) 
The quotation above expressed Alif's acceptance to the consequences when he has to ready if something occurs to him, to struggle for the life and his death. The Hand's threats had already terrorized him since the accusation, arrests, and the battle between both of them. He prepared himself in a long consideration between the choice to go on or stop, since the curiosity of seeking the truth of Alf Yeom attacked him. He understood and tried to believe of what he found so far.

\section{CONCLUSION}

Based on the analysis in the chapter III, this research concluded that the theory of ontological confrontation in Postmodernism based on Brian McHale is relevant to answer the statement of the problem in this study. The postmodernism emphasized that the plurality could create the confrontation that must be accepted by postmodern society, as when it is experienced by Alif as the main character of Alif The Unseen. From McHale's theory, it also stated that Alif as the Postmodern society must recognized the jinn creatures around him as the hacker who has the high ability and dependency of the technology. It is suggested to the next researcher to analyze this novel using the theory of deconstruction, determining the science fiction genre, and also the social conflict in the 21 era to bring the further aspects found in this novel.

\section{REFERENCES}

Adzani, Shabrina An. 2012. "Membaca Postmodernitas McHale Dalam Novel Percy Jackson: Pencuri Petir." Bunga Rampai Kajian Sastra Program Pascasarjana Ilmu Sastra FIB UGM 257.

CALD. Third Edition. Cambridge Advance Learner's Dictionary. Cambridge.

Coovadia, Zainab. 2015. At the Intersection of Politics and Science Fiction: Illuminating Concepts of Spatial Justice in Two Novels. Canada: University of Toronto.

Deskos, Nikolas. 2015. Beat Generation and Postmodernism: Deconstructing The Narrative of America. Amsterdam: University of Amsterdam.

Duignan, Brian. 2009. Encyclopaedia Britannica. Accessed April 20, 2018. https://www.britannica.com/topic/postmodernism-philosophy.

Eco, Umberto. 1979. The Role of The Reader: Explorations in The Semiotics of Text. Bloomington: Indiana University Press

Fredric Jameson, E. Ann Kaplan. 1988. "Postmodernism and Consumer Society" in Postmodernism and Its Discontent. London: Verso. 
Geurts, Merlijn. 2014. Toward Arab Spring Narratives: The Politics of Translated Arabic Literature in the Wake of the 2011 Arab Uprisings. Utrecht: Utrecht University.

Hassan, Ihab. 2001. "From postmodernism to postmodernity: The local/global context." Philosophy and Literature 1-13.

Light, L.E.H. __. Alif The Unseen: Cyberpunk, Middle Eastern Style. Accessed April 14, 2017. http://blacknerdproblems.com/alif-the-unseen-cyberpunk-middle-eastern-style/.

Lubis, Dr. Akhyar Yusuf. 2016. Postmodernisme: Teori dan Metode. Jakarta: RajaGrafindo Perkasa.

Lyotard, Jean Francois. 1984. The Postmodern Condition: A Report on Knowledge. Minnesota: University of Minnesota Press.

Maslin, Janet. 2012. Magic Aside, Even Genies and Demons Need Wi-Fi. June 24. Accessed March 29, 2017. http://www.nytimes.com/2012/06/25/books/alif-the-unseen-by-g-willowwilson.html.

Martin, Kelly. 2013. The Questionable Progression from Modernism to Postmodernism: Exploring Aesthetic Convergences in "Ullyses" and "Gravity's Rainbow". Florida: University of Florida.

Marzolphpa. 2007. "Arabian Nights", Encyclopaedia of Islam. Leiden: Brill.

McHale, Brian. 1987. Postmodernist Fiction. London: Routledge.

Merriam-Webster. s.v. "Plurality". Accessed January 17, 2018. http://www.merriamwebster.com.

Staeger, Uli. 2014. "The Arab Uprisings, Globalisation and Postmodernity." E-International Relations Students. August 5. Accessed January 21, 2018. http://www.eir.info/2014/08/05/the-arab-uprisings-globalisation-and-postmodernity/.

Toutonghi, Pauls. 2012. App for the Ancients. 10 August. Accessed January 17, 2018. http://www.nytimes.com/2012/08/12/books/review/alif-the-unseen-by-g-willowwilson.html.

Wilson, Gwendolyn Willow. 2012. Alif The Unseen. New York: Grove Press. . Accessed April 2017, 14. https://study.com/academy/lesson/postmodernism-inliterature-definition-lesson-quiz.html. 